\title{
The Role of the Incipits in Poulin's Le Vieux Chagrin
}

\author{
David Walker \\ York University
}

Encompassing the complexity of existence in the modern world demands a technique of ellipsis, of condensation. Milan Kundera, Art of the Novel.

The potential importance of pre-narrative and narrative beginnings, 1 or "incipits" in the signifying process has been underlined by a number of writers and critics. Louis Aragon, for example, held that a text was in large measure determined by its first sentence. ${ }^{1}$ Harry Levin affirms the close relationship of title and text, describing this relationship as "synecdochic" in nature. ${ }^{2}$ The similarity of the operations of an incipit to those of the "construction en abyme" has been signalled by Raymond $\mathrm{Jean}^{3}$ and by Jean Ricardou, for whom "le début d'un livre agence souvent un raccourci de son fonctionnement." ${ }^{\prime 4}$ These comments challenge the more traditional view of the incipits as subordinate to and simply illustrative of the signifying processes presented in the macro-text. A "générative" approach on the other hand confers upon these opening fragments - title, epigraph, chapter title, initial sentence - a principal role in the production of textual meaning.

Jacques Poulin's seventh novel, Le Vieux Chagrin, ${ }^{5}$ offers a particularly fine example of the dynamic interaction between incipits and the narrative they introduce. Increasingly Poulin's novels have been characterized by a highly compressed styled resulting from a tenacious struggle - often 
explicitly invoked in the novels - to find the "right" word. As the strategy of lexical condensation adopted by Poulin is also that which leads to the successful operation of an incipit - by permitting more complex interactions with the macro-text - his works offer a privileged area for the investigation of these textual beginnings.

In Le Vieux Chagrin a close re-reading of the incipits is authorized by an important episode in the novel. Here the writer-protagonist (Jim) comments upon the significance of the title of Hemingway's short story, Big Two Hearted River. Jim's explicitly figurative reading of the title gives us a better understanding not just of this particular short story but also of the American novelist's life and oeuvre. As well, the interpretation is relevant to the situation of the protagonist himself and of the character (La Petite) for whose benefit he has performed this explication. By extension, Jim's "lesson" is useful to the reader of Le Vieux Chagrin, suggesting the relevance of a similar analysis of the novel's own title and of other textual beginnings. While the following examination of the incipits does not claim the definitiveness of Jim's interpretation - he is after all seeking to give guidance to a psychologically scarred adolescent - nonetheless it is clear that these micro-texts, beginning with the title, are key indicators of the signifying processes at work in the novel.

\section{Pre-narrative Incipits}

\section{TITLE: LE VIEUX CHAGRIN}

The title appears at first simply to perform two of the conventional functions ${ }^{6}$ attributed to this incipit, the nominative (by designating a "character" in the novel - Jim's ageing cat), and the thematic (by signalling the emotional complex animating - and immobilizing - the protagonist). But the very merging of these two functions into a single unit has important implications. Most evidently, it provides an exemplary instance of lexical condensation, one of whose effects is to bring together disparate elements: the animal and the human, nature and culture, instinct and artifice. As well, this interweaving of character and theme in the 
title mirrors the work's blending of realism and dream in a narrative which seeks to harmonize the conscious and the unconscious. For if in the novel "Chagrin" is always only Jim's cat, each naming occurrence invests the text with the repressed and displaced trace of the deep distress ("le chagrin") which is Jim's other constant companion.

"LE VIEUX"

Both the article and the adjective in the title demonstrate a similar layering effect to that noted in the substantive. The definite article, for example, designates simultaneously the particular and the general and thus anticipates a narrative which, although ostensibly grounded in the concrete and the individual, is regularly absorbed into the uncanny and the oneiric.

The adjective "vieux" transposes into temporal terms the same layering effect. Most obviously, the adjective designates a linear temporality thematized for example in Jim's relationship with the teenaged "Petite." The adjective also emphasizes the longstanding and obsessive nature of Jim's distress, thereby anticipating the numerous narrative analepses during which the protagonist will relive - and perhaps exorcize - the pain of his traumatic abandonment by his wife. "Vieux" also initiates a cyclical temporality based upon recurrence. Jim's pain is "le [même] vieux chagrin" which returns throughout our individual and collective history. The protagonist's situation is thus transposable from the particular to the general: his "chagrin" is as old as literature itself, and the adjective designates it as a recurring constant in human experience.

\section{"CHA(T)GRIN"}

A final layer of signifying potential is embedded in the substantive's graphic and phonetic word-play. Here the incipit foregrounds its status as language, and thus as artifice. This consciousness of origins implies a self-reflexivity which will be realized in the text by a meta-fictional narrative in which the protagonist is a novelist attempting to write "une 
histoire d'amour," a story which in its revised form may well be entitled "Le Vieux Chagrin."

EPIGRAPH

CONVERSATION

(Sur le pas de la porte, avec bonhomie)

Comment ça va sur la terre?

- Ça va, ça va, ça va bien.

Les petits chiens sont-ils prospères?

- Mon Dieu, oui merci bien.

Et les nuages?

- Ça flotte.

Et les volcans?

- Ça mijote.

Et les fleuves?

- Ça s'écoule.

Et le temps?

- Ça se déroule.

Et votre âme?

- Elle est malade.

Le printemps était trop vert

Elle a mangé trop de salade.

Jean Tardieu

"Le Fleuve caché"

Both fragment and a complete text, the epigraph permits comparisons to be drawn with the novel, not only in terms of content - fleuve, temps, âme, printemps will reappear in the narrative, as will the poem's theme of disillusionment - but more interestingly in terms of formal signifying 
strategies. Tardieu's poem, for example, interweaves a highly mimetic text - dialogue, familiar diction, literal imagery - and one whose strangeness borders on the surreal: the mysterious questioner, the evolution of the imagery towards ever greater figurative weight, culminating in the total evacuation of realism in the final verses ("le printemps était trop vert/ Elle [l'âme] a mangé trop de salade"). This juxtaposition of representativity and anti-realism will be echoed in the novel by the blending of a resolutely realist narrative (Jim/ Chagrin/ Bungalow/ La Petite) with an anti-realist narrative (les traces de pas/ la caverne/ Marie K. - Marika) characterized by indeterminacy, invraisemblance, and other indications of the workings of dream and the unconscious.

Like the title, therefore, the epigraph conflates representativity and anti-realism. In so doing it mirrors a similar signifying procedure at work in the novel. Moreover, like the title, the epigraph refuses to hide its origin in language and clearly foregrounds its status as artifice. Through its constant recourse to the traditional norms of poetic diction - rhyme, rhythm, lexical repetition - the poem proclaims its rootedness in linguistic convention. As noted earlier this self-awareness is enacted in the novel by means of a meta-fictional narrative of which writing itself is the subject.

\section{Narrative Incipits: The First Chapter}

TitLE: "Les TRACES DE PAS"

As with the pre-narrative incipits the first chapter's title performs the conventional functions of naming an important narrative element and designating an essential theme: the quest for the ideal love object which begins with Jim's discovery of the footprints on the river's shore.

As with the title and epigraph, however, the incipit interacts with the narrative in more subtle and complex ways. The very implausibility of these footprints - they are exactly Jim's size but cannot be his (p. 9) endows the "traces de pas" with an ambiguous status: are they "real" or 
fantasized? This ambiguity will be echoed in the text by a double narrative in which realist and antirealist threads are seamlessly interwoven. Traces (literally) of a presence that is never actualized but always deferred, the footprints are the key indicator of the solipsistic nature of the protagonist's quest: "Marika n'existait pas vraiment, elle n'était que la projection d'un désir, une partie de moi-même ..." (p. 153).

The chapter title can be viewed also as indicative of the existence of a self-conscious (reflexive) dimension in the text. Neither totally outside nor fully within the narrative (Who in fact narrates these rubrics?), the chapter title arrests the narrative flow by focusing the reader's interpretive attention upon an element which will later reappear within the narrative. The rubric functions therefore as a semiotic counterpoint to the narrative's mimetic linearity. Sign of an authorial presence within the narrative, the chapter title is another indicator of the text's status as artefact and of its origin in writing. This dimension of self-reference, as noted earlier, will be echoed in the novel by a meta-fictional narrative thread.

\section{The First Sentence: "Le PRINTEMPS ETAIT ARRIVE"}

This concise opening sentence recapitulates the work of the prenarrative incipits and anticipates the activity of the narrative which follows. By reintroducing the vernal allusion of the epigraph ("le printemps était trop vert"), the first sentence immediately tempers the conventional spring-time associations - rebirth hope, love, fertility and signals a situation in which these positive values are under threat.

The springtime reference also imports into the narrative the double temporal structure already noted in the title ("vieux"): time in the novel is both linear and cyclical. Temporal linearity guarantees the representativity of the narrative (its "realism"), while time viewed as recurrence invests the work with symbolic potential, transforming the individual and finite into the universal and eternal.

The use of the pluperfect tense in the opening sentence is significant. The process delineated in Tardieu's poem - spring-time contributing to 
the sickness of the soul - is already underway and the naively positive vernal associations are already undermined. The incipit thus anticipates the failure of the protagonist's quest. Nonetheless, the positive connotation of "printemps" will be actualized in the less exalted but relatively optimistic second ending of the novel: the adoption of "la Petite."

The use of the pluperfect tense also inscribes in the narrative a past temporal dimension (the arrival of spring) which determines the present. This presence of the past is actualized in the narrative by the numerous analepses invoking decisive past experiences, whether of childhood (p. 10-11), of ephemeral happiness (p. 130-2), or of traumatic pain, as represented by the numerous flashbacks to the departure of Jim's wife.

\section{"La Caverne" and "La Maison"}

The opening chapter concludes with two descriptions, that of the cave to which the mysterious footprints lead the protagonist, and that of Jim's house, "une maison hétéroclite et dotée de plusieurs styles ..." (p. 10). Echoing the operation of the incipits, these initial descriptions are characterized by condensation and layering. Both appear rooted in representativity, yet both transcend the mimetic and reveal a marked tendency towards both anti-realism and reflexivity.

The description of the cave, for example, is highly concrete and yet certain details impart a metaphorical dimension to this space. The protagonist's very entry into the cave - "en se faufilant par une brèche très étroite" (p. 9) - invests this space with an erotic dimension and evokes certain symbolic connotations of the cave (woman, the womb). That Jim's relation with this cave goes back to his childhood, and that he detects in the cave "l'âme de quelqu'un" (p. 10) confer upon this space associations that far transcend a merely naturalistic description.

This undermining of the representational is furthered by the fact that the cave is above all a literary space. The 1001 Nights is the only object discovered in the cave, and it is the memory of this book which will 
remain strongest in Jim's mind after his first visit to the cave and which will interrupt his own writing (p. 11). The "caverne" is thus closely linked to the metafictional dimension of a text in which writing itself is narrativized.

The description of the protagonist's house introduces another apparently representative object which functions both metaphorically and self-reflexively. A number of details undermine the naturalistic nature of the description: the allusion to "son aspect un peu étrange" (p. 10); the explicit reference to the house as "la maison de mon enfance" (p. 10); and perhaps most significantly, the ritualistic crossing of the house from one side of the river to another, a passage with which Jim imaginatively identifies (p. 11).

It is, however, the structure of the house which most clearly portrays the non-representational nature of the description. The house is a trilevel space with each level clearly distinct from the other. The main floor, for example, is reserved for the activities of everyday life; the second floor is explicitly associated with childhood and dream (the family bedrooms) and revery ("la galerie vitrée"). The third floor attic is of course the space of writing, the space where language and imagination appropriate and synthesize the data of experience garnered from the rest of the house and from the world outside. The description of the house is therefore figurative as well as representational: its construction mirrors the various levels of the narrator's experience of life. In addition to this important metaphorical component, the description of the house functions reflexively - as a mise en abyme - by mirroring the work's tripartite narrative structure: representative, anti-realist, and metafictional.

\section{Incipits and the Narrative}

Although the description of the protagonist's house offers perhaps the clearest example of the specular relationship between incipit and text, all the "beginnings" studied here possess a similar layering structure, the result of radical lexical condensation. The incipits constitute 
emblematic verbal structures whose (vertical) integration is projected on to the (horizontal) narrative in the form of three distinct but intertwined narrative threads:

1) a representative narrative - the mimetically based recounting of Jim's conscious interaction with the external world;

2) an anti-realist narrative - the metaphor-centred narrative whose principal elements (the footprints, the cave, Marie K. - Marika) are generated by dream and other workings of the unconscious;

3) a metafictional narrative - the story of the writing by the protagonist of a novel (this novel?).

These narratives, although distinct, are permeable one to the other, and numerous transpositions and cross-overs occur throughout the novel. Bungalow, for example, arrives in Jim's kitchen as if in response to an invitation to Marika that Jim has recently left in the cave. Jim for his part will regularly transpose into his novel elements of his "real-life" experience. And Marika, while integral to the anti-realist narrative, will by her absence both inspire and block Jim in his writing. This interweaving of diverse narrative threads corresponds to the radical tendency towards condensation which characterizes the incipits. Both incipit and narrative seek integration and harmonization. Both aim at reducing difference while simultaneously affirming its presence.

\section{THE INCIPITS AND EXPERIENCE}

In examining the operation of the incipits in Le Vieux Chagrin, we have noted how these fragments interact both with the content of the story (nominative and thematic functions) and with the formal organisation of the narrative. The radical condensation of meaning characteristic of the incipits is mirrored by the interweaving of various narrative "threads," each corresponding to a layer of meaning discernible in the incipits. Both incipit and narrative reveal a centripetal tendency towards integration and harmonization. This impulse towards unifying 
disparate elements can be interpreted as reflecting an aesthetic parti pris favouring a Hemingwayesque economy of verbal resources. Indeed, Jim's comments on the aphorism "A coeur vaillant, rien d'impossible" summarizes, on the phrastic level, what appears to be the poulinien textual ideal: "C'était une phrase courte, dépouillée, bien ramassée, et on ne pouvait pas enlever ni déplacer un mot. Elle avait toutes les qualités qui plaisaient au vieux Hémingway" (p. 89).

Our analysis has been confined thus far to an investigation of certain formal and stylistic traits of the novel. The total exclusion of an "existential" dimension to this study of the incipits would however be a mistake. While most of Jim's reflections upon literature are related to formal and stylistic considerations, the writer-protagonist also affirms explicitly - if somewhat sheepishly, as such declarations are hardly fashionable - his belief in an extra-textual mission for his writings: ". . . je nourrissais l'ambition naïve et démesurée de contribuer, par l'écriture, à $l^{\prime}$ avènement $d^{\prime}$ un monde nouveau. .." (p. 139). This potential for literature to effect change in the "real world" is in fact actualized by "La Petite," whose gradual recovery is in part due to her reading of Jim's work: "Mais quand j'ai lu tes livres, c'est comme si on m'avait donné la permission d'être moins agressive. .." (p. 139).

This validation of the experiential in literature suggests another less formalist basis for the workings of the incipits. The tendency of these textual fragments to integrate disparate elements can be seen as a product of desire, the verbal expression of an existential quest for unity. Both Jim and "La Petite" are attempting to heal the wounds of past experience which have left them in a state of inner conflict and fragmentation: "... nous étions tous les deux emmurés en nous-mêmes et occupés à recoller les morceaux de notre passé" (p. 120). From this perspective the textual penchant for condensation and integration constitutes a displaced expression of a profound desire for self-reconciliation and for a more harmonious relationship with the world.

The ultimate outcome of this quest for the unity and integration of the self remains ambiguous. On the one hand there is defeat. Jim fails in 
his pursuit of the ideal love object: Marika remains absent, at most a "silhouette," at best "un rêve magnifique." Jim also fails to write his novel about love.

And yet there are victories: Jim and "La Petite" will form an alliance and struggle together in their search for harmony. Jim will begin a new version of a love story ("il y a des choses qui s'en viennent" p. 136), integrating elements of his earlier effort. These are small but real steps forward. And above all, there is a textual victory, one in which the triumph over fragmentation is demonstrable, a victory most convincingly achieved in the complex and productive activity of the incipits.

\section{Notes}

'Louis Aragon, Je n'ai jamais appris à écrire ou les incipit (Geneva: Editions d'Art Albert Skira, 1969), p. 145.

${ }^{2}$ Harry Levin, "The Title as Literary Genre," Modern Language Review 72 (1971), xxiv.

3Raymond Jean, "Commencements romanesques," in Positions et oppositions sur le roman contemporain (Paris: Editions Klincksiek, 1971), p. 138-39.

${ }_{4}^{4} J e a n$ Ricardou, "La Bataille de la phrase," Poétique 274 (1970), p. 231.

${ }^{5}$ Jacques Poulin, Le Vieux Chagrin (Montréal: Leméac, 1989).

'Richard Sawyer, "Fictional Titles: A Classification," The University of Toronto Quarterly 60:3 (Spring 1991), p. 374-88. 